\title{
Apocalipsis de Solentiname (Julio Cortázar): literatura fantástica y género apocalíptico en el contexto latinoamericano
}

\author{
Mónica ZÚÑIGA \\ Escuela de Ciencias del Lenguaje-Instituto Tecnológico de Costa Rica
}

\begin{abstract}
RESUMEN
El presente artículo estudia las relaciones entre la literatura fantástica, específicamente los espacios de tránsito, y la apocalíptica en tanto género literario y categoría teológica, a través de la propuesta de Julio Cortázar en su cuento de 1976, Apocalipsis de Solentiname. El abordaje teológico-literario permitirá ahondar en la visión de mundo del texto y, al mismo tiempo, intentará descifrar las claves de la narración, que se muestra por un lado como un relato de gran contenido autobiográfico pero, por otro, señala una dimensión fantástica de horror, vaticinio y esperanza.
\end{abstract}

Palabras clave: Apocalíptica, literatura fantástica, espacios de tránsito, esperanza.

\section{Apocalypsis of Solentiname (Julio Cortázar): fantastic literature and apoca- lyptical gender in the Latin American context}

\begin{abstract}
This article analyzes relations between apocalyptical literature-as theological category- and fantastic literature, specifically transit spaces and the approach of Julio Cortázar shown in his 1976 tale, Apocalypsis of Solentiname. The theological-literary approximation allows to identify the world vision of the text and, at the same time, will try to decode the keys of narration that shows itself as a tale with many autobiographical doings, but in the other hand, point a fantastic dimension with horror, prophecy and hope.
\end{abstract}

Key words: Apocalyptical gender, fantastic literature, transit spaces, hope.

SUMARIO: I.Introducción. II.Un contexto tangencial. III.Lo fantástico redirigido hacia lo político. III.1.Espacios de tránsito y literatura fantástica. IV.La apocalíptica como género literario: (Cortázar y un título coincidente). IV.1.Literatura de perseguidos. IV.2.Literatura desde abajo. IV.3.Literatura, crisis y esperanza. IV.4.La apocalíptica y lo fantástico. V.Conclusiones.

Para su bien o para su mal, el escritor latinoamericano (acaso como consecuencia de sus cateos en profundidad, de su sensibilidad especialmente entrenada, de sus intuiciones en permanente confrontación) 
no puede ya cerrar las puertas a la realidad, y si ingenuamente procura cerrarlas, de poco le valdrá ya que la realidad entrará por la ventana. ${ }^{1}$ Situación del escritor en América Latina, Mario Benedetti (1967)

\section{Introducción}

Julio Cortázar (1914-1984) escribió en 1976 uno de los pocos cuentos cuyo título sugiere una espacialidad corroborable desde el inicio: el archipiélago de Solentiname, en Nicaragua. Dicho relato pertenece a su cuentario Alguien que anda por ahí, publicado en 1977 en México y que abre, según los estudiosos, un espacio intermedio entre lo escrito anteriormente y su admiración y apoyo permanente ${ }^{2}$ hacia la Revolución Cubana iniciada en 1959.

M. E. Twardy (2008, http://www.ucm.es/info/especulo/) señala que cuando presentó este libro en Argentina, "los censores no dudaron en verlo como una provocación y un atentado a las autoridades". Además, estos cuentos manifiestan una ruptura con la línea literaria que Cortázar venía trabajando desde los años cuarenta; en ese sentido, es posible trazar un antes y un después en la vasta producción del argentino, como lo advierte Francisco E. de la Guerra, hablando de la década de los 70 que vio nacer los cuentos de Alguien que anda por ahí:

En ese periodo se afianzan los cambios y hábitos en el escritor argentino- Mientras muchos de sus colegas que en el decenio anterior habían manifestado su respaldo a la revolución cubana retrocedían y otros rompían abiertamente con ella, Cortázar reafirmó su adhesión a ese proyecto e inició su etapa de "militancia intelectual”-por llamarla así-en la izquierda latinoamericana. (de la Guerra, 2000: 133)

En efecto, ese cuentario y otros textos posteriores evidencian un cambio de ruta en la producción del argentino que, sin embargo, no abandonó nunca sus temáticas fantásticas. Este hecho, sin duda, genera una serie de interpretaciones (o sospechas) que serán abordadas en las siguientes líneas, si bien no de manera definitiva (sobre Cortázar se ha dicho mucho y no pretendo sino elaborar una modesta aproximación que vincule el aspecto teológico poco trabajado en su obra). Al mismo tiempo, dichas "lecturas" tienen que ver, por un lado, con la reescritura de la ficción tan

${ }^{1}$ Epígrafe de corte comprometido y a la vez figurado; nótese la personificación de la realidad y la mención de la ventana que, en la literatura fantástica, es un espacio de tránsito y de aparición de "lo otro". Nótese también lo doble en la afirmación bien o mal. El cuento aludido participa de esta doble estructura, como se analizará en los apartados siguientes.

${ }^{2}$ A pesar del caso Padilla, que dividió a los intelectuales del boom y a pesar de la "excomunión” que le dictó Fidel Castro (de la Guerra, 2000: 172) 
privilegiada por el escritor argentino, pero también con la honestidad propia del autor, honestidad que se mezcla con un relato de fuerte contenido político y, al mismo tiempo, con un recurrente aspecto onírico y fantasmagórico presente en la mayoría de sus cuentos.

Ahora bien, aparte del aspecto literario este estudio señala algunas nociones fundamentales dentro del género de la apocalíptica, pues el texto participa de algunos de estos elementos. En otras palabras, lo apocalíptico cruza todo el texto, desde sus condiciones de producción-tema que solo menciono-hasta su contenido y visión de mundo. De esta forma, Apocalipsis de Solentiname será abordado desde la óptica literaria y semiótica, más los elementos propios de la apocalíptica en tanto género particular vinculado con la fantasía, la crisis-angustia y el binomio resistenciaesperanza. Además, si bien no es el objeto de estudio de esta investigación, se repasarán -tangencialmente- algunos elementos propios del contexto histórico en el que apareció el cuento aludido para ubicar mejor la problemática realidad-ficción tan aludida por algunos estudiosos. El análisis de los diversos enfoques permitirá establecer la visión de mundo presente en el texto y la propuesta cortazariana, cuya amalgama liga lo fantástico con lo político de forma magistral.

\section{Un contexto tangencial}

Apocalipsis de Solentiname inicia con un marcado tono biográfico. En efecto, el texto señala una visita a Costa Rica y al país vecino, Nicaragua, ocurrida en 1976. Los nombres de los protagonistas que lo reciben en Costa Rica son todos reales: Carmen Naranjo (Ministra de Cultura por aquel entonces y fallecida en 2011), Samuel Rovinsky (dramaturgo costarricense), los poetas nicaragüenses Ernesto Cardenal y José Coronel Urtecho, entre otros ${ }^{3}$. El encuentro de todas estas personalidades centroamericanas con el padre de los cronopios y famas está documentado a través de fotos y notas periodísticas tanto de Costa Rica como de Nicaragua. En este sentido, el texto muestra una suerte de introducción autobiográfica.

${ }^{3}$ Sergio Ramírez cuenta que dicho encuentro fue "un sábado [...] un viaje clandestino, porque pasamos de lejos el control militar del puerto de San Carlos, un poblado en la confluencia del río San Juan con el lago. Nunca se enteró Somoza de aquella visita de Julio Cortázar a Nicaragua, en perpetuo estado de sitio" (www.revistadelauniversidad.unam.mx/0104/pdfs/el_evangelio.pdf ). 

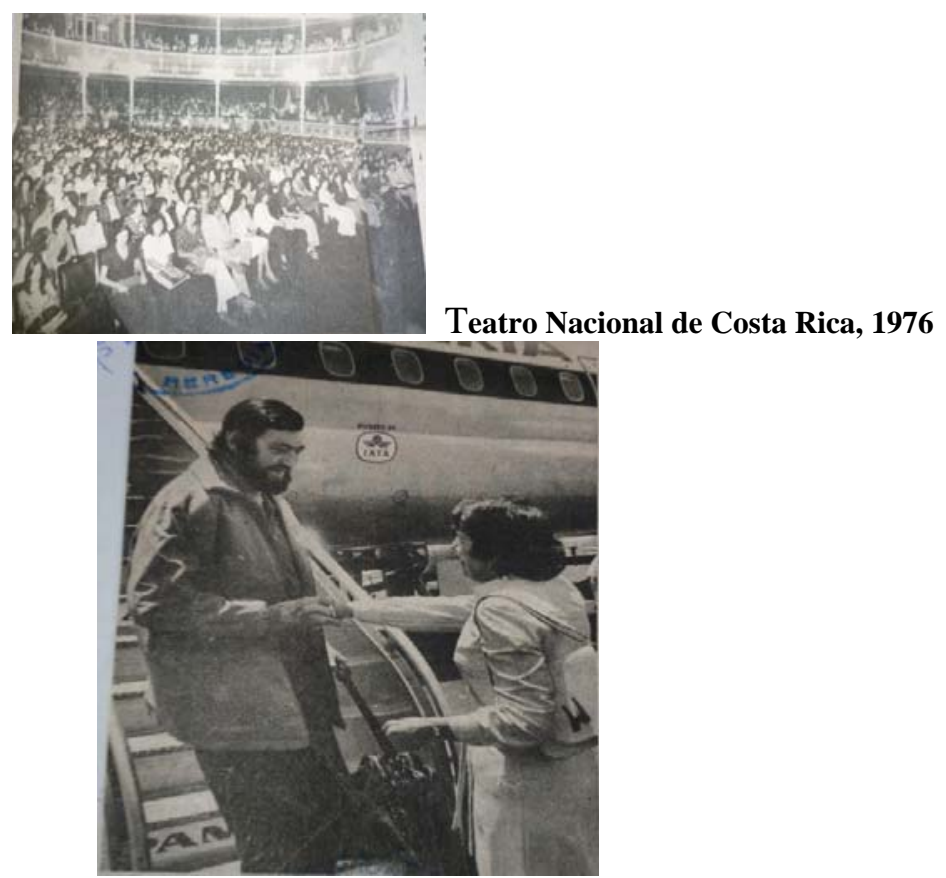

Cortázar y Carmen Naranjo, 1976

Cortázar estuvo en Costa Rica y compartió con muchas personas en el Teatro Nacional. Allí impartió tres conferencias: "Lo fantástico en la literatura latinoamericana", "Los intelectuales y la literatura" y "Los caminos de un escritor" (Excélsior, 13 de abril, 1976: 3). El teatro se llenó y, tras esas conferencias, el argentino viajó a Solentiname. A ese lugar llegó "entrada la noche” (1998: 156). Hasta ese desplazamiento, lo autobiográfico predomina; sin embargo, al llegar a Solentiname la atmósfera comienza a cambiar y el culmen de la "aparición fantástica” acontecerá en París. Esta mezcla entre lo real y lo fantástico es resaltada por María Cristina Pons cuando dice que en este cuento se plantea la problemática entre el arte y la realidad histórica, la cual irremediablemente se filtra en la creación artística, en la ficción (1994: 194). El cuento se escribió en 1976, y siendo supersticiosos -como lo fue Cortázar-, vemos que en ese año ocurrieron varios hechos:

- el golpe de Estado en Argentina.

- El año del dragón según el horóscopo chino (y de su terremoto).

- Los sucesos de Vitoria (España).

- Los famosos secuestros que dieron origen a la película La noche de los lápices.

- El atentado terrorista contra el vuelo 455 de Cubana. 
Algunos de estos acontecimientos ocurrieron antes de la datación de su cuento; sin embargo, otros muestran una suerte de vaticinio juánico, en el sentido de profecía pronta a cumplirse. Sirvan estos datos como contexto tangencial, deleznable en la mayoría de sus textos, pero valioso en este particular, como lo ha señalado Jonathan Tittler: "La lectura histórica de Apocalipsis de Solentiname es lícita dentro del contexto fictivo y viceversa" (1986: 116).

\section{Lo fantástico redirigido hacia lo político}

En Apocalipsis de Solentiname hay, desde luego, un juego recurrente dentro de la narrativa cortazariana que privilegia la esfera de lo fantástico. Aunque algunos señalen que no hay tal esfera (como María Elena Pons o Helio Gallardo ${ }^{4}$ ), sino una metáfora de lo vivido en América Latina durante aquella época, lo cierto es que en este relato lo fantástico está presente aunque dirigido hacia un compromiso político.

El argumento del cuento es sencillo: el narrador-protagonista viaja a Costa Rica y de ahí a Nicaragua. Allí, visita el archipiélago de Solentiname donde fotografía varios cuadros hechos por los lugareños. También participa de una misa dirigida por el padre Cardenal y luego se marcha a Costa Rica y a La Habana. Después regresa a París y revela las fotos que tomó en Solentiname. Sin embargo, en su apartamento mira las fotos reveladas, pero éstas se han transformado: de ser cuadros inocentes (naíf) y prístinos, pasan a conformar escenas de terror que van desde las torturas hasta asesinatos y traiciones reales (como el asesinato de Roque Dalton). El narrador-protagonista entra en pánico pero, minutos después, su novia lo visita en el apartamento y rompe ese "apocalipsis". Ella comienza a ver las fotos y observa solo las imágenes de los cuadros nicaragüenses, nada inusual... El cuento termina con una sensación de incertidumbre, pues quien narra y su novia ven imágenes distintas de un mismo objeto pero, además, el narrador cierra el relato con el deseo de formular una pregunta reiterada dentro del texto que tiene que ver con Napoleón a caballo saliendo de una foto... Esa pregunta solo se pensó... El protagonista ni siquiera se atrevió a decirla.

Nos dice Tzvetan Todorov que en la literatura, lo fantástico irrumpe cuando:

el que percibe el acontecimiento debe optar por una de las dos soluciones posibles: o bien se trata de una ilusión de los sentidos, de un producto de imaginación, y las leyes del mundo siguen siendo lo que son, o bien el acontecimiento se produjo realmente, es parte integrante de la realidad, y entonces esta realidad está regida por leyes que desconocemos. (Todorov, 1981: 15)

\footnotetext{
${ }^{4}$ Helio Gallardo (1981). Pensar en América Latina. Heredia: EUNA y Pons; María Elena (1992), "Compromiso político y ficción en "Segunda vez" y "Apocalipsis de Solentiname" de Julio Cortázar”, Revista Mexicana de Sociología, vol. 54, nº 4, UNAM.
} 
En ese sentido, el texto de Cortázar "vacila" entre dos posturas: o lo visto en el departamento de París es real (tan real como Napoleón pero no como Napoleón en el s. XX) o hay un desvarío y no hay tal visión. El sentido de la vista no le alcanza (y tampoco al lector) para aprehender ese acontecimiento ambiguo. Además, el suceso ocurre en la noche (y con licor que, sin duda, altera los sentidos) espacio propicio para la indefinición: “Anochecía y yo estaba solo, Claudine vendría al salir del trabajo para escuchar música y quedarse conmigo; armé la pantalla y un ron con mucho hielo...” (Cortázar, 2000: 158).

Pero también el narrador vacila entre dos intenciones: si el texto inicia con un tono biográfico, este "marco" aleja, aunque de manera artificiosa, cualquier momento fantástico. En otras palabras, el juego empieza por introducir al lector en una atmósfera de apariencias reales, de acontecimientos reales para luego hacer "emerger” lo fantástico de manera abrupta y violenta, dislocando de esta forma la apreciación sobre lo acontecido. Nuevamente, hay que indicar con Todorov que:

El término percepción es aquí importante: las obras ligadas a esta red temática ponen de manifiesto su problemática, y en especial, la del sentido fundamental, la vista ("los cinco sentidos no son sino uno solo: la facultad de ver”, decía Louis Lambert): hasta tal punto que sería posible considerar todos estos temas como "temas de la mirada". (Todorov, 1981: 66)

En Cortázar dicho tema es recurrente. Solo basta con pensar en sus textos más conocidos y antologados, Las babas del diablo, Axolotl, La isla al mediodía, y hasta en la curiosa (para este estudio) auto-identificación que el mismo argentino hace con respecto a la figura de Pablo-Saulo de Tarso:

Yo te diría, aunque parezca una cosa literaria y un poco narcisista que, a mi manera, a mi pobrecita manera, tuve mi camino de Damasco. No me acuerdo muy bien de lo que pasó en ese camino, creo que Saulo se cayó del caballo y se convirtió en Pablo ¿¿no? Bueno, yo también me caí del caballo y eso sucedió con la revolución cubana. (Montero, 1991: 797)

Ahora bien, lo que Saulo perdió en ese camino, aunque Cortázar no lo recuerde bien, fue por cierto el sentido de la vista. Luego de esa "caída del caballo", quedó ciego pero, por un milagro, volvió a ver el mundo, aunque con una perspectiva diferente.

En ese sentido, los tópicos de la percepción y de la mirada, son fundamentales dentro de los textos del argentino y, en este, particularmente. El ojo que ve o cree ver son una misma cosa: ambas acciones valen. Por eso Charles Grivel afirma que lo fantástico: 
no se deja encasillar en un género o en "lo imaginario", porque sobrepasa por definición la noción que se pueda tener de ella. Sobrepasa también la literatura, el trabajo de la imagen y aún las prácticas artísticas; se vive en lo cotidiano, desde el momento que una pantalla lo capta, desde que los ojos se abren ávidamente para volverse hacia la visión que engendraron (los ojos obvio). (Grivel, 1992: 7-8)

En este caso, la visión de lo fantástico convoca una fuerte simbología. Lo fantástico irrumpe en la noche, espacio que "engendra igualmente el sueño y la muerte, las ensoñaciones y las angustias, la ternura y el engaño [...] entrar en la noche es volver a lo indeterminado, donde se mezclan pesadillas y monstruos, las ideas negras” (Chevalier y Gheerbrant, 1999: 753-754). De este modo, lo visto por el narrador-protagonista comporta un elemento de indefinición que permea buena parte del relato y también su desenlace. No es casual entonces, la visión de lo macabro en la noche, ni tampoco la incertidumbre en la que se colocan tanto el narrador como el lector del texto.

Las fotos, sin embargo, fueron tomadas al mediodía que, como advierten Chevalier y Gheerbrant, es la hora "en la que no hay sombra, es el sello de la profecía, la culminación de la luz espiritual...una suerte de instante sagrado, un detenimiento en el movimiento cíclico, antes de que se rompa el frágil equilibrio y que la luz bascule hacia su declinación" (1999: 703). Muestran el lugar de la inocencia, de lo limpio y primigenio, justo en el límite del día; afianzan una imagen "prístina de mundo", que será trastocada y contrastada con las tinieblas de París y la visión apocalíptica de sangre y caos.

Continuando con la irrupción de lo fantástico, es necesario prestar atención a las siguientes oraciones:

\begin{tabular}{|l|}
\hline $\begin{array}{l}\text {...pequeño mundo de Solentiname, rodeado de agua y de esbirros como estaba rodeado el } \\
\text { muchacho que miré sin comprender... }\end{array}$ \\
\hline ...el muchacho estaba ahí en un segundo plano clarísimo \\
\hline Un fondo confuso de casas y árboles. \\
\hline Se piensa lo que se piensa, eso llega siempre antes que uno mismo y lo deja tan atrás... \\
\hline Estúpidamente me dije que se habrían equivocado en la óptica.... \\
\hline Tampoco mi mano obedecía \\
\hline Sé que seguí; frente a eso que se resistía a toda cordura... \\
\hline Nunca supe si seguía apretando o no el botón... \\
\hline ...mirando hacia la izquierda donde un grupo confuso de cinco o seis \\
\hline Y aunque la foto era borrosa yo sentí y supe y vi \\
\hline$\ldots$...de golpe la pantalla se llenó de mercurio y de nada \\
\hline $\begin{array}{l}\text { Uno no sabe cómo ni por qué hace las cosas cuando ha cruzado un límite que tampoco } \\
\text { sabe }\end{array}$ \\
\hline ...creo que vomité o solamente lloré y después vomité o no hice nada... \\
\hline No sé cuánto tardé en recorrer... \\
\hline ...pero me acuerdo que pensé vagamente en preguntarle una estupidez... \\
\hline
\end{tabular}


Cuadro 1. Oraciones que muestran la ambigüedad de las escenas y que van de la página 158 a la 160. El realce en negrita es mío.

Estas oraciones resaltadas surgen junto a la "transformación” de los cuadros-foto (hermosos), a escenas terribles y crean así una esfera de indefinición y de rompimiento de límites. El concepto de realidad se disloca o se amplía. En ese sentido, Mery Erdal Jordan nos recuerda que “...es posible señalar que la narrativa fantástica mantiene en común, a lo largo de toda su evolución, el cuestionamiento de la supuesta vigencia de una única noción de realidad, la denominada empírica en el siglo XIX y convencional en el presente” (1998: 110). Las imágenes amenas captadas con el lente de la cámara del narrador se transforman en escenas apocalípticas, de muerte y virulencia. La realidad capturada, no coincide entonces con lo visto en París y, en ese sentido, podemos hablar de que o bien hay una tergiversación de planos, o bien hay una irrupción de lo fantástico-terrorífico, algo fugaz pero suficiente como para causar vómito en el narrador y duda en quien lee. Luis Eyzaguirre (1986) diría que más bien asistimos a una "interpenetración de los planos”, es decir, a una fusión entre lo real-irreal matizada por el tema del doble. Veamos ese matiz doble al que se refiere Eyzaguirre:

- El texto se data en 1976 en dos ciudades (San José y La Habana).

- Hay dos espacios contrapuestos (Solentiname-París).

- La gente de Solentiname interpreta doblemente el texto del arresto de Jesús en Getsemaní (Jesús=ellos).

- El narrador dice haber viajado durante dos meses.

- El cuadro de una madre con dos niños.

- Unos niños jugando entre palmeras, igualitos a las pinturas (o sea, dobles).

\section{III.1. Espacios de tránsito y literatura fantástica}

Si hablamos de literatura fantástica hay que referirse necesariamente al espacio, ya que esta problematización guarda estrechas relaciones con la diégesis del texto, o como diría Lotman "los modelos más generales sociales, religiosos, políticos, morales del mundo, mediante los cuales el hombre interpreta en diversas etapas su historia espiritual, la vida circundante, se revelan dotados invariablemente de características espaciales” (Lotman, 1970: 271). Por lo cual, las oposiciones alto/bajo, cielo/ tierra, aquí/allá, izquierda/derecha, y demás, derivan en una base organizadora de elementos, una imagen de mundo, finalmente. En Apocalipsis de Solentiname la organización espacial es fundamental para extraer una interpretación ligada con lo fantástico pero, a la vez, con lo ético. 
En el texto del argentino sobresale un tipo de espacio: el de tránsito ${ }^{5}$, que según, Margarita Rojas y Flora Ovares, tiene que ver con "el ámbito intermediario que se percibe como un túnel, un hueco entre dos mundos coexistentes, entre dos dimensiones de la realidad" (Rojas y Ovares, 1999: 7).

Estos espacios de tránsito permiten el paso de una realidad a otra en medio de la cotidianidad. En ellos, el desplazamiento de los personajes o de los acontecimientos intenta disolver los límites que, en este caso, están constituidos por lo fantástico o lo real. En Apocalipsis de Solentiname, este espacio lo ofrece la cámara fotográfica que invierte los planos de la realidad al mostrar escenas "transformadas". La imagen captada por la cámara corresponde a un momento ameno, de armonía y paz primigenias; sin embargo, en París (que constituye el "lugar ameno" del narrador") las imágenes se trastocan y dan paso a la pesadilla, al apocalipsis.

En ese sentido, continúan Rojas y Ovares señalando que:

el ojo y la cámara son el punto de unión donde se invierten misteriosamente las imágenes del mundo, concavidad oscura donde se trastoca la realidad, se enlazan lo interno y lo externo, la conciencia con el inconsciente. El ojo y la cámara tienen en común con los lugares intermediarios la capacidad de abrirse y cerrarse, para detener o dejar pasar de un lado a otro. (1999: 8 y 9)

Cuando el narrador "revela" los rollos (las fotografías de cuadros, vaquitas y niños sonriendo tomadas en Solentiname), estos se convierten en escenas de muerte y tragedia, con un matiz a-temporal y a-geográfico, que homologa a cada torturado y a cada asesino, con cualquier persona. Así lo detalla el cuento: “...y entonces sí, apreté el botón como si con eso pudiera salvarlo de la infamia de esa muerte y alcancé a ver un auto que volaba en pedazos en pleno centro de una ciudad que podía ser Buenos Aires o Sao Paulo...” (2000: 159). La muerte y la violencia se trasladan al apartamento del narrador, mediante el tránsito de la cámara, que permite el movimiento de esas escenas y su trastocamiento. Dichas escenas provocan

${ }^{5}$ Ejemplo de espacios de tránsito son el túnel (el hoyo de Alicia en el país de las maravillas), el umbral (el umbral del baño en donde se encuentran por primera vez los protagonistas de la novela costarricense María la noche), las puertas (Alí Babá y los 40 ladrones), ventanas (La isla al mediodía de Julio Cortázar), estaciones de tren o metro (la estación desde donde parte Harry Potter a la escuela de hechiceros en el libro I), las cámaras fotográficas (Las babas del diablo, también de Cortázar), los puentes (El cuento Lejana), pinturascuadro (como el del barco en The voyage of the dawn treader, de C. S. Lewis), etc. En todos estos textos se muestra un umbral que puede ser una puerta, una ventana, un lente...Los análisis de estos escritos son múltiples (solo de Las mil y unas noches hay un sinnúmero de interpretaciones), sin embargo, lo que aquí se acota es la presencia de umbrales, espacios mágicos que conducen a otros mundos o dimensiones. 
extrañamiento y catarsis en el narrador, quien vomita y se esconde en el baño ante lo "otro" que apareció frente a sus ojos. En esa línea, nos recuerda Grivel que "la literatura fantástica atenta contra la persona: la deforma, la enfrenta con lo desconocido (con un desconocido que no tiene lugar de ser), la introduce precisamente en aquello que ella repudia” (Grivel, 1992: 7).

Asimismo, el espacio de tránsito permite la irrupción de la vida en el arte y viceversa, lo cual constituye uno de los tópicos más antiguos de la literatura y la cultura en general. En otras palabras, el texto de Cortázar intenta priorizar una de las dos, y determina que el arte va antes que todo: "pero por qué los cuadritos primero, por qué la deformación profesional, el arte antes que la vida y, por qué no, le dijo el otro a éste en su eterno indesarmable diálogo fraterno y rencoroso, por qué no mirar primero las pinturas de Solentiname, si también son la vida, si todo es lo mismo" (2000: 158).

En este párrafo está condensada buena parte de lo que ocurre en todo el texto: los planos de la realidad se entremezclan, el arte y la vida parecen oponerse, la vida y la muerte se enfrentan pero, al final, todo es lo mismo o constituye tal vez un solo mundo. Pero ¿qué es todo y qué es lo mismo? La realidad, en su acepción más totalizadora, implica quizá ambas posturas, lo grotesco y lo hermoso, la náusea y la esperanza, la ingenuidad y la perversión. Pero lo que se aprehende de ella nunca es suficiente para definirla. En palabras de Rojas y Ovares, "sea cual fuera la forma que adquiera, el contacto entre ambos mundos siempre cambia al sujeto [...] pues no se puede actuar sobre el exterior sin afectarnos a nosotros mismos" (1999: 18).

En el cuento de Cortázar, la cuestión ética se desprende de unas fotos "inocentes” que revelan la bestialidad de la que es capaz el ser humano, y en nuestro caso específico, la muerte que rodeó y rodea la vida en América Latina. En otras palabras, a la par de la hermosura de las tierras americanas, de su gente y su inocencia; existe la posibilidad (y también ha estado presente la evidencia) de las atrocidades de regímenes autoritarios que han traído sufrimiento y vergüenza. En el texto, el bimonio vida-muerte está presente. Los espacios de tránsito implican un desplazamiento que va desde lo fantástico hasta la "aparente realidad", no exenta de fantasmas ni de muerte. Por eso, la propuesta del padre de los cronopios no olvida el infierno ni el cielo, por eso son posibles apocalipsis en lugares amenos y lugares amenos en medio un apocalipsis.

Los espacios de tránsito son quizá la metáfora de que la realidad es dinámica, nunca fija ni acabada; por eso mismo aterradora e inaprehensible. También, puede significar -siguiendo la cuestión ética- un vaivén infinito pues "en todos nosotros duerme un sádico, un fascista, un nazi y solo nuestra vigilancia ideológica, nuestra plena toma de conciencia humana puede reducir eso a límites ínfimos, aunque probablemente no los destierre nunca” (1991: 793). 


\section{La apocalíptica como género literario: (Cortázar y un título coincidente)}

El tema de la apocalíptica ha sido vastamente trabajado desde la teología; sin embargo, las relaciones entre literatura fantástica y apocalíptica no son muy abundantes $^{6}$.En este caso específico, debemos señalar que la apocalíptica atraviesa el cuento de Cortázar desde sus condiciones de producción (es decir, lo extratextual, no estudiado aquí plenamente) hasta su contenido primordial. Los elementos apocalípticos presentes en el relato implican, en un primer momento, una revisión de lo que se denomina literatura de perseguidos, es decir, una producción textual que surge como respuesta a una condición de dominación (es el caso recurrente de la literatura apocalíptica del pueblo de Israel en tiempos de cautiverio o conquista.

Un segundo aspecto está relacionado con la escritura desde abajo, lo cual significa un reposicionamiento de la autoría, que lejos de ubicarse desde el poder de las jerarquías, apuesta por mostrar la voz de los débiles, que en el contexto judeocristiano, pueden ser muchos grupos (piénsese en los niños, los empobrecidos, las mujeres, etc.). También hay que abordar aunque sea de forma breve, la literatura surgida en tiempos de crisis y el llamado que ésta hace a la resistencia, en medio de un mundo injusto y caótico. Si bien el mundo mostrado por la literatura apocalíptica es maniqueo (hay solo malos y buenos), el llamado a tener esperanza y a confrontar la injusticia, va más allá de esta postura: el género como tal obedece a una estructura, y es justamente ese andamiaje, lo que se evidencia dentro del texto de Cortázar.

\section{IV.1. Literatura de perseguidos}

El teólogo español Xabier Pikaza advierte, entre otras cosas, que la apocalíptica“...expresa la experiencia literaria propia de un pueblo que sabe interpretar su realidad con hondura (sabiduría) humana y describirla con dramatismo, empleando fuertes imágenes "sobrenaturales", que sirven para conocer mejor lo que existe en el mundo y para así cambiarlo” (Pikaza, 2001: 13).

Este género implica un relato de dolor, frustración y derrota. Para muchos fue una forma catártica de vencer al enemigo, a la tribulación. En el caso israelita, suponía la continua invasión de sus territorios y su minúsculo poder sobre los ejércitos que los conquistaban. En el caso del cuento de Cortázar, el pueblo de Solentiname participa de esa pequeñez frente a las fuerzas opresoras y de muerte. Nótense la fragilidad y la inocencia que se desprenden del siguiente fragmento:

\footnotetext{
${ }^{6}$ Es más, hay quienes dicen que el Apocalipsis es literatura fantástica, al igual que muchos de los textos de Borges, Hoffman y hasta Tolkien (es el caso del estudio de Juan Esteban Londoño, (2009). "Sobre monstruos y esperanzas: literatura apocalíptica y literatura fantástica”, Literatura apocalíptica y literatura fantástica. Vida y Pensamiento, vol. 29, n 2, San José: Editorial UBL.
} 
“...vaquitas enanas en prados de amapola, la choza de azúcar de donde va saliendo la gente como hormigas, el caballo de ojos verdes contra un fondo de cañaverales [...] el lago con botecitos como zapatos” (1991: 156).

Otro de los aspectos fundamentales de este género es el ligado con las interrogantes sobre la justicia de Dios y el sentido de la acción humana, así como su búsqueda por el origen del mal. Además, es un género sinónimo de "literatura de perseguidos”7 . A este respecto, es fundamental el siguiente párrafo del cuento:

\begin{abstract}
Al otro día era domingo y misa de once, la misa de Solentiname en la que los campesinos y Ernesto y los amigos de visita comentan juntos un capítulo del evangelio que ese día era el arresto de Jesús en el huerto, un tema que la gente de Solentiname trataba como si hablaran de ellos mismos, de la amenaza de que les cayeran en la noche o en pleno día, esa vida en permanente incertidumbre... (Cortázar, 2000: 157)
\end{abstract}

Desde esa tribulación y ese fondo hay que entender las imágenes virulentas, monstruosas y sangrientas evidenciadas en los textos canónicos y apócrifos y, por supuesto, en el de Cortázar (me refiero a las escenas de torturas, asesinatos, explosiones, etc.). La vida rodeada de muerte ejemplifica de manera certera esa persecución tanto en el texto leído por el sacerdote como en la interpretación que las humildes gentes hacen de él.

\title{
IV.2. Literatura desde abajo ${ }^{8}$
}

El teólogo chileno Pablo Richard menciona un eventual origen de la literatura de género apocalíptico. Según él, el retorno a Palestina de la elite que había estado exilada en Babilonia genera un primer movimiento apocalíptico o de reforma, dividido en dos tendencias:

${ }^{7}$ Concepción valiosísima para este análisis, sobre todo porque el arresto de Jesús en Getsemaní es el culmen del relato de los evangelios sinópticos. Jesús fue perseguido al igual que la gente de Solentiname; de ahí el paralelismo y la cuestión doble de la estructura del relato, ya que la gente interpreta doblemente: saben que Jesús fue perseguido, pero también lo aplican a sí mismos.

${ }^{8}$ No valen en este sentido las críticas sobre el aburguesamiento de Cortázar, o el argumento de que él amaba más París que Argentina, como señalaban algunos críticos entre esos José Blanco Amor o Mempo Giardinelli. El primero decía, a propósito de un poema compuesto por Cortázar para el Ché, que la Argentina del novelista era intelectual y pequeñoburguesa en su esencia (1972: 241) El segundo hablaba del desfase de Cortázar por vivir fuera de su patria (Giardinelli citado por de la Guerra, 2000: 191). Cuando se dice literatura desde abajo, se debe entender la opresión y la minoría excluida del poder, de la que Cortázar autor-narrador también formaba parte. 
una dominante hierocrática (sacerdotal), inspirada en la escatología apocalíptica de Ezequiel [...] su programa es la reconstrucción del pueblo a partir de la reconstrucción del templo y del culto. [...] Pronto este movimiento pierde su dimensión escatológica apocalíptica y se transforma en un movimiento de control de la comunidad (Esdras, Nehemías y Crónicas). La otra tendencia tiene un carácter profético-popular [...]. Busca la reconstrucción de Israel, no fundamentalmente a partir de las estructuras, sino de la reconstrucción del pueblo mismo. (Richard, 1994: 23)

De este modo, la apocalíptica ve surgir dos modelos: uno que afianzaba el retorno a la institucionalidad (las leyes y el poder de antaño) y otro de corte más popular, gestado a partir de una identidad histórica de opresión. En ese sentido, la apocalíptica como género literario va constituyendo una amalgama de ideas e imágenes que tienen que ver, por un lado, con la creación de mitos, seres fantásticos y hechos cosmogónicos pero, a la vez, con una marcada identidad histórica, ligada con la resistencia desde abajo (desde el pueblo, los campesinos, los pobres) frente a distintos imperios y amenazas.

Así pues, el sujeto social de la apocalíptica es el oprimido, lo que no excluye un carácter universal y totalizante con el que pueden identificarse muchas personas en contextos, culturas y siglos disímiles (Richard, 1994: 38). Esto es justamente lo que sucede con una de las lecturas del cuento de Cortázar, pues la alabanza de las gentes campesinas e incluso de su arte, expresado a través de las pinturas, comporta una dimensión de identidad desde abajo, desde los empobrecidos y perseguidos:

No me acuerdo quién me explicó que eran trabajos de los campesinos de la zona, ésta la pintó el Vicente, ésta es de la Ramona, algunas firmadas y otras no pero todas tan hermosas, una vez más la visión primera del mundo, la mirada limpia del que describe su entorno como un canto de alabanza [...]. (Cortázar, 2000: 156)

\section{IV.3. Literatura, crisis y esperanza}

Al mismo tiempo, Jean Pierre Prévost (1994) nos dice que la apocalíptica como género literario se caracteriza por surgir en tiempos de crisis significativas ${ }^{9}$, pues:

así ocurre, concretamente, con el más antiguo de los apocalipsis conocidos: el libro bíblico de Daniel, que nos lleva al período de Antíoco Epífanes (175-164) y

${ }^{9}$ Es interesante esta afirmación, pues implica un paralelismo con el cuento de Cortázar escrito en 1976, en tiempos de crisis en América Latina, pero a la vez, en la antesala del triunfo de la revolución sandinista. Aquí, nuevamente, se ve una coincidencia entre el título del cuento y el momento en que surge. 
de la sublevación de los macabeos (166-160). En el otro extremo, o sea, a mediados del siglo II de nuestra era, nos encontramos también en período de crisis, con la persecución de los cristianos por un lado (véase, por ejemplo, la carta de Plinio el Joven al emperador Trajano, escrita hacia el 111-112), y el aplastamiento de la sublevación judía de Bar Kokba (132-135), por otro lado. (Prévost, 1994:57-58)

La apocalíptica traduce sentimientos de malestar, impotencia y angustia surgidos a partir de las diferentes invasiones y agresiones del pueblo judío. Su atmósfera, por ende, es pesimista y tormentosa; sin embargo, transluce resistencia y a veces, esperanza, como en el caso del Apocalipsis de Juan. En el cuento de Cortázar, esta impotencia se muestra con la irrupción de lo fantástico, es decir, con las escenas de muerte: “...gente amontonada a la izquierda mirando los cuerpos tendidos boca arriba, sus brazos abiertos contra un cielo desnudo y gris...[...] una sucia luz cayendo de la alta ventanilla enrejada, la mesa con la muchacha desnuda boca arriba..." (2000: 158-159). Su relato surge como dije, en tiempos convulsos, pero lo horroroso se manifiesta en el cuento, y surge rodeado por la crisis y la inminencia de algún ataque.

Un aspecto notable referido a la apocalíptica es el de un género buscador de consolación, tanto en su contenido como en su gestación en tanto texto de funciones catárticas. Prévost afirma que "es verdad que la dimensión de consuelo y de esperanza no aparece a primera vista, pero está allí en filigrana y se resiste a todos los tormentos y ansiedades que se agitan en la superficie” (1994: 64). Tanto los apocalípticos apócrifos como los canónicos animan a los creyentes en medio de las tribulaciones: los incitan a ser perseverantes y a tener esperanza. Esta dimensión es la que debería estudiarse y promocionarse más.

El texto de Cortázar, en ese sentido, aboga también por una transformación de la realidad que pasa -inevitablemente- por lo monstruoso y la náusea. Sin embargo, también deja una sensación de impotencia o pesimismo, característica de su época, bajo la forma de una pregunta con doble respuesta "qué pasaría si alguna vez después de una foto de familia el papelito celeste de la nada empezara a llenarse con Napoleón a caballo” (Cortázar, 2000: 156).

Hay también en este relato un aspecto teológico-bíblico que Tittler ha señalado: una oposición entre el Eros dirigido hacia Claudine y el Caritas mostrado al pueblo nicaragüense. (1986: 113). En ese sentido, es posible decir entonces que el texto de Cortázar aboga por una identificación con el pueblo nica, desde abajo y con el mayor de los tipos de amor y esperanza que el evangelio cristiano profesa. Por consiguiente, "la caridad nunca dejará de ser" ( $1^{\mathrm{a}}$ Cor.13) se asimila a "la resistencia nunca dejará de ser” o, como diría el padre Cardenal dándole vuelta al verso bíblico y aplicándolo a América Latina “solo el amor es revolucionario”.

\section{IV.4 La apocalíptica y lo fantástico}

Por su parte, Juan Esteban Londoño señala que: 
La narrativa apocalíptica se ubica en una dimensión espacial muy concreta. Se trata de un mundo sobrenatural, extraño y mágico, concebido geográficamente como sobre este mundo o debajo de él. A veces divide al cielo en niveles, y separa las acciones del relato entre ángeles y demonios, personajes extraños y seres animalescos o telúricos con algunos rasgos humanos que les permite interactuar con el narrador. (Londoño, 2009)

En ese sentido, la narrativa apocalíptica es maniquea pues establece dos bandos definidos: los malvados y los buenos, los santos y los demonios, los condenados y los salvos. Este fragmento del cuento así lo evoca: "mirando la esquina de Corrientes y San Martín y el auto negro con los cuatro tipos apuntando a la vereda donde alguien corría con una camisa blanca y zapatillas...” (Cortázar, 2000: 158). Así pues, la visión maniquea, la referencia a los colores blanco y negro, el que alguien salga con camisa blanca de un tiroteo, por ejemplo, indican los puntos de encuentro entre el texto de Cortázar y el género apocalíptico. ${ }^{10}$. La visión maniquea por tanto, está presente también en este cuento de Cortázar y obedece a unas de las formas apocalíptico-fantásticas de este tipo de relatos.

Asimismo, Londoño advierte que la apocalíptica, ejerce la función de la literatura fantástica para el judaísmo tardío y el cristianismo primitivo. En ella, se halla la elaboración de sueños y monstruos, de lo humano y lo bestial. Allí está plasmado el realismo contado en lenguaje simbólico y mítico. Con ella se denuncia la injusticia y se anuncia el reino de los santos. (Londoño, 2009)

${ }^{10}$ Esta es una de las características que más se critican cuando se habla- por ejemplo- de literatura y realismo social. Se ha dicho reiteradamente que la "literatura de calidad" no debe ser maniquea; sin embargo, este modelo es necesario y hasta pedagógico, como lo ha demostrado Bruno Bettelheim en su libro clásico sobre los cuentos de hadas. Según él, en el cuento de hadas se "describe el mundo: los personajes encarnan la maldad más atroz o la bondad menos egoísta. Un animal o solo devora, o solo ayuda. Todos los personajes son esencialmente, de una sola dimensión, lo que permite que el niño comprenda fácilmente sus acciones y reacciones” (2012: 106). Esta lectura de los cuentos de hadas no es la única, es más la lectura hecha por los niños, no obstante, en el caso que nos atañe, hay que puntualizar que por ejemplo, todo el texto bíblico de Apocalipsis, tiene una clara función pedagógica, que es a su vez, una de las características del género apocalíptico. El artículo “Apocalipsis: una pedagogía de resistencia y esperanza” de Cecilia Leme esgrime esa línea, pues como ella afirma "con esa propuesta y a través de un estilo literario cargado de simbolismos, imágenes y figuras maravillosas, Juan escribe a una comunidad amenazada y perseguida y tiene una intencionalidad pedagógica específica: invitar a la resistencia y restaurar la esperanza de un pueblo cansado de la dominación e inseguro ante la violencia de un sistema político opresor”(2011: 13). 
En ese sentido, vemos una doble función de este tipo de literatura: por un lado "imagina” y, por otro, apela a la organización concreta de una resistencia para soñar y luchar al mismo tiempo. Es decir, la apocalíptica no niega la "bestialidad humana” traducida en genocidios, opresión económica, discursos falaces, injusticias, etc., pero es consciente de que la vida también puede ser hermosa, como lo muestra el penúltimo párrafo del cuento del argentino: "Qué bonitas te salieron, esa del pescado que se ríe y la madre con los dos niños y las vaquitas en el campo, espera y esa otra del bautismo en la iglesia, decíme quién los pintó, no se ven las firmas” (Cortázar, 2000: 159). No está de más decir que esta doble intención, imaginaciónresistencia (fatalidad-esperanza o binomio vida-muerte) coincide también con una estructura doble en el texto de del escritor argentino, cuyo ejemplo más evidente lo constituyen los datos de la fecha en que fue escrito el texto (es decir, los espacios de San José y La Habana, respectivamente).

Un último aspecto ligado con la apocalíptica (en este caso específico), es de las semejanzas entre el profeta Juan de Patmos y el narrador del texto. Hay particulares coincidencias en la categoría del narrador; es decir, tanto el Juan del Apocalipsis como el narrador que habla desde Solentiname participan de varias escenas monstruosas. Ambos son narradores protagonistas, ambos son testigos de la apertura de unos rollos (sellos en el caso de Apocalipsis) y ambos se sobrecogen con las escenas de muerte y destrucción que salen "literalmente" cuando se abren esos textos. El narrador también tiene visiones como Juan y el espacio desde donde surgen estas visiones está rodeado por agua: la isla de Patmos en el caso de Juan, el archipiélago de Solentiname en el caso del narrador del cuento de Cortázar. Una última coincidencia entre los narradores es que son hombres del libro; es decir, "literatos" que conforman una cultura de sabios, escribas; una minoría instruida pero perseguida (Pikaza, 1999: 13). De ahí que el cuento mencione esta idea cuando dice

...¿ipor qué no vivís en tu patria, qué pasó que Blow- up era tan distinto de tu cuento, te parece que el escritor tiene que estar comprometido? A esta altura de las cosas, ya sé que la última entrevista me la harán en las puertas del infierno, y seguro que serán las mismas preguntas, y si por caso es chez San Pedro la cosa no va a cambiar ¿a usted no le parece que allá abajo escribía demasiado hermético para el pueblo?

\section{Conclusiones}

Apocalipsis de Solentiname es un cuento complejo, difícil de estudiar porque no solo implica un análisis de elementos fantásticos, espacios de tránsito y cuestiones apocalíptico-teológicas, sino también un recorrido histórico e ideológico fusionado magistralmente con la ficción. No es redundante mencionar que la realidad, rebasada como se nos aparece en este cuento, nos confronta con lo desconocido, lo bestial y lo mutable: la vida está rodeada de muerte, los rollos con las plagas se siguen 
abriendo y, aunque el narrador apriete el botón intentando salvar al poeta, no logra evitar la muerte, su muerte...

La literatura que surge en tiempos de crisis es una suerte de catarsis, de antídoto contra la locura; por eso, las escenas de muerte y suplicio no son negadas, sino matizadas con pasajes de armonía y belleza: las plagas en el Apocalipsis de Juan aparecen junto al cielo nuevo y la tierra nueva; los asesinatos, en el texto de Cortázar, se muestran a la par de los cuadros inocentes y las amistades entrañables o el amor erótico.

El mundo maniqueo, el rompimiento del límite, la amenaza de perder la vida, la persecución y el martirio, todo esto se amalgama en el texto de Cortázar: su visión de mundo deriva entonces en una pregunta cuya respuesta es una terrible expresión. La sola presencia de una interrogante (o de su contestación) es lo que produce la angustia sentida dentro del relato, pero a la vez deja paso a la construcción de un final que podría ser de esperanza (los cuadros vuelven a ser hermosos cuando los ve Claudine...) Para bien o para mal, la realidad entra por la ventana; entra en el texto y "nos penetra", como seres humanos, y desde luego, como latinoamericanos.

Por eso, en palabras de Grivel, lo fantástico, en su acepción más totalizadora,

Es allá, surgido de una oscuridad distinta pero impenetrable, de zonas externas y lejanas, de planetas inaccesibles, de intermundos, dentro de catacumbas, bajo subterráneos, cerca, sin embargo, de la mesa donde nos sentamos a conversar, de la cama donde descansamos: lo fantástico representa la existencia. (1992: 5)

La literatura fantástica y el género apocalíptico implican una forma de evasión, distante de la irresponsabilidad y el egoísmo: son más bien un intento desesperado de querer aprehender esa otra realidad que se esfuma a cada paso.

\section{BIBLIOGRAFÍA}

AA.VV.

1986 Lo lúdico y lo fantástico en la obra de Julio Cortázar. Coloquio Internacional. Centre de Recherches Latino-Americaines. Université de Poitiers. Caracas: Editorial Fundamentos.

BENEDETTI, Mario.

1967 "Situación del escritor en América Latina”, en El ejercicio del criterio [1981]. México: Ed. Nueva Imagen.

BETTELHEIM, Bruno.

2012 Psicoanálisis de los cuentos de hadas. Barcelona: BooketBIBLIA DE NUESTRO PUEBLO

2007 Texto de Luis A. Schökel. Bilbao: Ediciones Mensajero. 
BLANCO AMOR, José.

1972 “Julio Cortázar”, en Giancoman Helmy (coord.), Homenaje a Julio Cortázar,. Nueva York-Barcelona: Las Américas.

CORTÁZAR, Julio.

1991 Rayuela. (Edc. crítica de Julio Ortega y Saúl Yurkievich). España: Archivos, CSIC.

2000 Cuentos completos I y II. Madrid: Alfaguara.

CHEVALIER, J. y A. GHEERBRANT.

1999 Diccionario de los símbolos. Barcelona: Herder.

DE LA GUERRA, Francisco.

2000 Julio Cortázar, de literatura y revolución en América Latina. México: Unión de Universidades de América Latina.

ERDAL JORDAN, Mery.

1998 La narrativa fantástica. Evolución del género y su relación con las concepciones del lenguaje. Madrid: Iberoamericana.

Excélsior

1976 (13 de abril, Costa Rica)

GALLARDO, Helio.

1981 Pensar en América Latina. Heredia: EUNA.

GRIVEL, Charles.

1992 Fantastique fiction. Paris: Presses Universitaires de France.

LEME, Cecilia.

2011 “Apocalipsis: una pedagogía de resistencia y esperanza”, Siwô. Revista de Teología, Heredia: Universidad Nacional.

LONDOÑO, J. Esteban.

2009 "Sobre monstruos y esperanzas: literatura apocalíptica y literatura fantástica”, Literatura apocalíptica y literatura fantástica. Vida y Pensamiento, vol. 29, n² 2, San José: Editorial UBL.

LOTMAN, I.

1996 "El texto en el texto”, en La semiosfera I. Semiótica de la cultura y del texto. Madrid: Cátedra.

2000 La semiosfera III. Semiótica de las artes y de la cultura. Madrid: Cátedra. MONTERO, Rosa.

1982 "El camino de Damasco de Julio Cortázar”, en Julio Cortázar [1991]. Rayuela. (Edc. crítica de Julio Ortega y Saúl Yurkievich). España: Archivos, CSIC.

PIKAZA, Xavier.

2001 Apocalipsis. Estella (Navarra): Editorial Verbo Divino.

PONS, María Elena.

1992 “Compromiso político y ficción en 'Segunda vez’ y 'Apocalipsis de Solentiname’" de Julio Cortázar”, Revista Mexicana de Sociología, vol. 54, $n^{\circ} 4$, UNAM. 
PRÉVOST, Jean Pierre.

1994 Para leer el Apocalipsis. Estella (Navarra): Editorial Verbo Divino. RAMÍREZ, Sergio.

S/F. "El evangelio según Cortázar”.

www.revistadelauniversidad.unam.mx/0104/pdfs/el_evangelio.pdf

RICHARD, Pablo.

1994 Apocalipsis. Reconstrucción de la esperanza. San José: DEI.

ROJAS, Margarita y Flora OVARES.

1999 "Espacios de tránsito en los cuentos fantásticos de Julio Cortázar”, Letras, $n^{\circ}$ 31, Costa Rica: EUNA.

SOLER, Joaquín.

1977 Entrevista a Julio Cortázar. Serie A fondo. Televisión Española SORIANO, Osvaldo y Norberto COLOMINAS.

1979 “Julio Cortázar: lo fantástico incluye y necesita la realidad”, en Julio Cortázar [1991]. Rayuela. (Edc. crítica de Julio Ortega y Saúl Yurkievich). España: Archivos, CSIC.

TWARDY, Maria E.

2008 “'Alguien que anda por ahí’: Julio Cortázar, literatura y exilio”. http://www.ucm.es/info/especulo/numero40/coexilio.html

TODOROV, Tzvetan.

1981 Introducción a la literatura fantástica. México: Premia Ed. 